\title{
Spatial Distribution and Environmental Significance of Phosphorus Fractions in River Sediments and Its Influencing Factor from Hongze and Tiaoxi Watersheds, Eastern China
}

\author{
Ja Bawk Marip ${ }^{1 *}$, Xuyin Yuan ${ }^{1,2}$, Hai Zhu1 ${ }^{1}$, Isaac Kwesi Nooni, ${ }^{3,4}$, Solomon O.Y. Amankwah ${ }^{3}$, Nana \\ Agyemang Prempeh ${ }^{5}$, Eyram Norgbey ${ }^{1}$, Taitiya Kenneth Yuguda', Zaw Myo Khaing1 \\ ${ }^{1}$ Key Laboratory of Integrated Regulation and Resources Development of Shallow Lakes of Ministry of \\ Education, College of Environment, Hohai University, Nanjing 210098, China \\ ${ }^{2}$ Fujian Provincial Key Laboratory of Eco-Industrial Green Technology, College of Ecology and Resources \\ Engineering, Wuyi University, Wuyishan, China \\ ${ }^{3}$ School of Geographical Sciences, Nanjing University of Information Science and Technology, Nanjing \\ 210044, China \\ ${ }^{4}$ Binjiang College of Nanjing University of Information Science and Technology, No. 333, Xishan Road, Wuxi \\ 214105, Jiangsu Province, China \\ ${ }^{5}$ School of Geosciences, University of Energy and Natural Resources, PMB, Sunyani-Ghana \\ * Correspondence: maripjabawk@gmail.com (J.B.M) and yxy_hjy@hhu.edu.cn (X.Y)
}

Received: date; Accepted: date; Published: date

Abstract: River sediment from two inflow watersheds (Hongze and Tiaoxi) to Hongze and Taihu Lake in Eastern China was analyzed by the sequential extraction procedure. This study aimed to explore a spatial distribution of phosphorus fractions in river sediments and analysed the relationship between different phosphorus fractions and their environmental influence on the sediments within different watersheds in Eastern China. Five fractions of sedimentary phosphorus, including freely sorbed phosphorus, were all analyzed $\left(\mathrm{NH}_{4} \mathrm{Cl}-\mathrm{P}\right)$, redox-sensitive phosphorus (BD$\mathrm{P})$, bound phosphorus metal oxide (NaOH-P), bound phosphorus calcium (HCl-P) and residual phosphorus (Res-P). The order of rank of the $\mathrm{P}$ fractions for the river Anhe was $\mathrm{HCl}-\mathrm{P}>\mathrm{NaOH}-\mathrm{P}>\mathrm{BD}-$ $\mathrm{P}>\mathrm{NH}_{4} \mathrm{Cl}-\mathrm{P}$; whereas that of the Suihe river was $\mathrm{HCl}-\mathrm{P}>\mathrm{BD}-\mathrm{P}>\mathrm{NaOH}-\mathrm{P}>\mathrm{NH}_{4} \mathrm{Cl}-\mathrm{P}$. For the rank order of the Hongze watershed, $\mathrm{HCl}-\mathrm{P}$ was higher while the $\mathrm{NH}_{4} \mathrm{Cl}-\mathrm{P}$ contents were significantly lower. The rank order for the Dongtiaoxi river was $\mathrm{NaOH}-\mathrm{P}>\mathrm{HCl}-\mathrm{P}>\mathrm{BD}-\mathrm{P}>\mathrm{NH}_{4} \mathrm{Cl}-\mathrm{P}$ and that of Xitiaoxi river was $\mathrm{NaOH}-\mathrm{P}>\mathrm{BD}-\mathrm{P}>\mathrm{HCl}-\mathrm{P}>\mathrm{NH}_{4} \mathrm{Cl}-\mathrm{P}$. Compared with phosphorus forms of Tiaoxi watershed, $\mathrm{NaOH}-\mathrm{P}$ contents were significantly higher in converse of $\mathrm{HCl}-\mathrm{P}$ contents were significantly higher in Hongze watershed while both in $\mathrm{NH}_{4} \mathrm{Cl}-\mathrm{P}$ contents were significantly lower. Variations may be attributed to differential discharge of $\mathrm{P}$ watershed form due to land use changes and urban river ambient conditions.

Keywords: Phosphorus fractions, Phosphorus, Sediment, Tiaoxi, Hongze, Watershed

\section{Introduction}

Eutrophication is one of the world's most severe pollution issues. Phosphorus, a well-known limiting factor has exhibited potential environmental contamination abilities for water body eutrophication [1,2]. Rapid population growth, industrialization and increased agricultural production account for the huge release into the environment of untreated sewage and waste [3]. As a consequence, the anthropogenic contribution of mobilized phosphorus $(\mathrm{P})$ in watersheds flows into rivers and lakes, exacerbating the risk of surface water eutrophication [4].

Sediment is an essential source of nutrients and contributes nutrients to the freshwater bodies. $\mathrm{P}$ in water has external and internal sources; $\mathrm{P}$ can come from external sources (agricultural and natural) or point sources (domestic effluents and industrial) [5]. Many small and large rivers in cities 
of Eastern China are polluted due to anthropogenic activities and topography, leading to several ecological issues in the aquatic environment.

Sequential extraction methods have been commonly used in sediment phosphorous morphology studies in recent years. Sediment $\mathrm{P}$ is classified into various forms, such as exchangeable P, P bounded to calcium, P bounded to $\mathrm{Al}$ and Fe oxides, inorganic P (Inorg-P) and organic P (Orgp) [6-10]. The variations of total $\mathrm{P}$ and its fractions in sediments, which increased from a low concentration at a depth of $20-30 \mathrm{~cm}$ to a higher concentration. This represented the anthropogenic effects of phosphorus and the mechanisms of P release from sediment in the Hongfeng Reservoir [11].

Luo et al [12]) explored the environmental influence of sediments as well as the characteristics of phosphorus, total phosphorus (TP), and dissolved total phosphorus (DTP) fractions of water and excess water in sediments in Xiangxi Bay. Song et al [13] focused on the spatial distribution of $\mathrm{P}$ fractions in the Meiliang Bay sediment using the SMT sequential process. Zhang et al [3] explored phosphorus properties of surface water in the different river systems and its relationship to environmental impact in Eastern China by SMT fractionation.

Shujuan et al [14] studied the amounts and Phosphorus forms in the Haihe River surface sediment using a sequential chemical extraction procedure. Rivers in Eastern China run from west to east. Phosphorus from anthropogenic activities in the watersheds get into the rivers and lakes, which increase the risk of water eutrophication [4]. It is therefore important to identify P-sources (both externally and internally) to help control inputs of nutrients into freshwater systems. However, there is few information about the attributes of $\mathrm{P}$ and its environmental influence in the various watersheds.

Hongze and Tiaoxi watersheds were selected in this work because they have been significantly affected by anthropogenic activities such as agriculture, domestic and industries. The Hongze and Tiaoxi watersheds are of ecological importance to the Hongze and Taihu lakes, and a number of environmental protection initiatives such as domestic wastewater treatment and enforcement of China's water pollution control law have made a great deal of effort to control pollution loads. It is then important to assess the overall phosphorous content of the sediment and the concentrations of different phosphorous fractions as well as their influence factors in different watersheds.

Studying the spatial variations and attributes of $\mathrm{P}$ in the sediments in this study area will provide good information of the river sediments and their influence factors, and to develop a theoretical basis for the management of the environment. The goal of this research was to (1) study the composition and spatial variation of phosphorus forms in sediment, (2) Evaluate the relationship between the $\mathrm{P}$ forms and the physicochemical properties and (3) study the environmental significance of P in the area of research.

\section{Materials and Methods}

\subsection{Study area}

Sediments were sampled from Hongze and Tiaoxi watersheds in Eastern China. Tiaoxi watershed is situated in the northwest of the province of Zhejiang with a latitude of $30^{\circ} 07^{\prime} \sim 30^{\circ} 41^{\prime} \mathrm{N}$ and a longitude of $119^{\circ} 07^{\prime} \sim 119^{\circ} 08^{\prime} \mathrm{E}$. The length of the watershed is $157.4 \mathrm{~km}$ and a catchment area of more than $4570 \mathrm{~km}^{2}$. Tiaoxi watershed (Dongtiaoxi and Xitiaoxi Rivers) is composed of two major tributaries which converges at Bai Quetang Bridge in Huzhou city and then flow into the Taihu Lake [15]. 
The annual runoff of Tiaoxi River is $14.93 \times 109 \mathrm{~m}^{3}$ and is one of the major tributaries of the Taihu Lake. Hongze watershed includes the Anhe River and Suihe River. They represent large variations in eutrophy and are anthropogenically influenced to varying degrees [15].
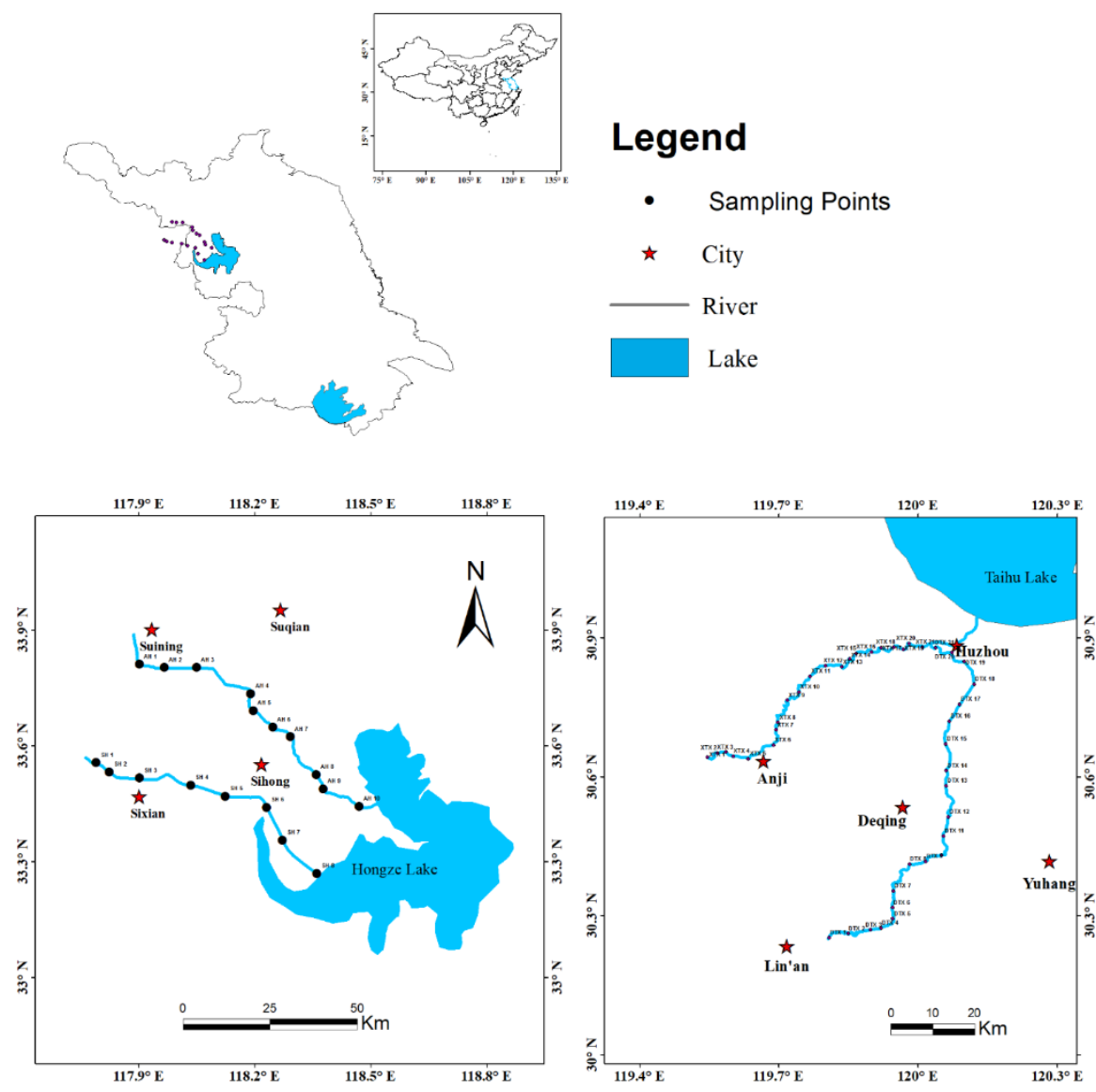

Fig. 1 Map of the sampling sites of different watersheds [15]

\subsection{Sampling sites}

River sediment samples (Fig. 1) were taken from the sampling sites at the main sites and tributaries of the watersheds of Hongze and Tiaoxi. Sampling sites were distributed throughout the study area. Both the natural environment characteristics and spatial distribution of all forms of land use in the study area were considered. To obtain representative river sediments, samples $(0-10 \mathrm{~cm})$ were collected from upstream and downstream sites in the Tiaoxi and Hongze watersheds where there were no impacts on industrial waste disposal sites, livestock excrement sites and domestic waste disposal sites.

Samples were promptly enclosed in plastic bags made from polyethylene. All samples were placed in an incubator and taken to the laboratory. From Fig.1, sample collection points in the Hongze watershed were labelled 'AH1-AH10' and 'SH1-SH8' while that of Tiaoxi watershed (DTX, XTX) were labelled 'DTX1- DTX21' and 'XTX1-XTX 21'. Samples were freeze-dried, grounded and passed through a 20-mesh sieve for homogenization and analysis.

\subsection{P fractions in sediment}

The P content from river sediments mainly originate from inorganic $P$ fractions, hence, the study uses inorganic $\mathrm{P}$ fractions. The varying phosphorus contents was determined using the sequential extraction scheme according to Psenner et al ([16] and Hupfer et al [17]. The extraction process 
separated Fractions of inorganic phosphorus (IP) in the sediment into freely sorbed $\mathrm{P}\left(\mathrm{NH}_{4} \mathrm{Cl}-\mathrm{P}\right)$, redox-sensitive $\mathrm{P}(\mathrm{BD}-\mathrm{P})$, metal-oxide-bound (NaOH-P) and calcium-bound $\mathrm{P}(\mathrm{HCl}-\mathrm{P})$.

The distinction between TP and IP is the remnant fraction $\mathrm{P}$ (Res-P), consisting of organic $\mathrm{P}$ and refractory P compounds.

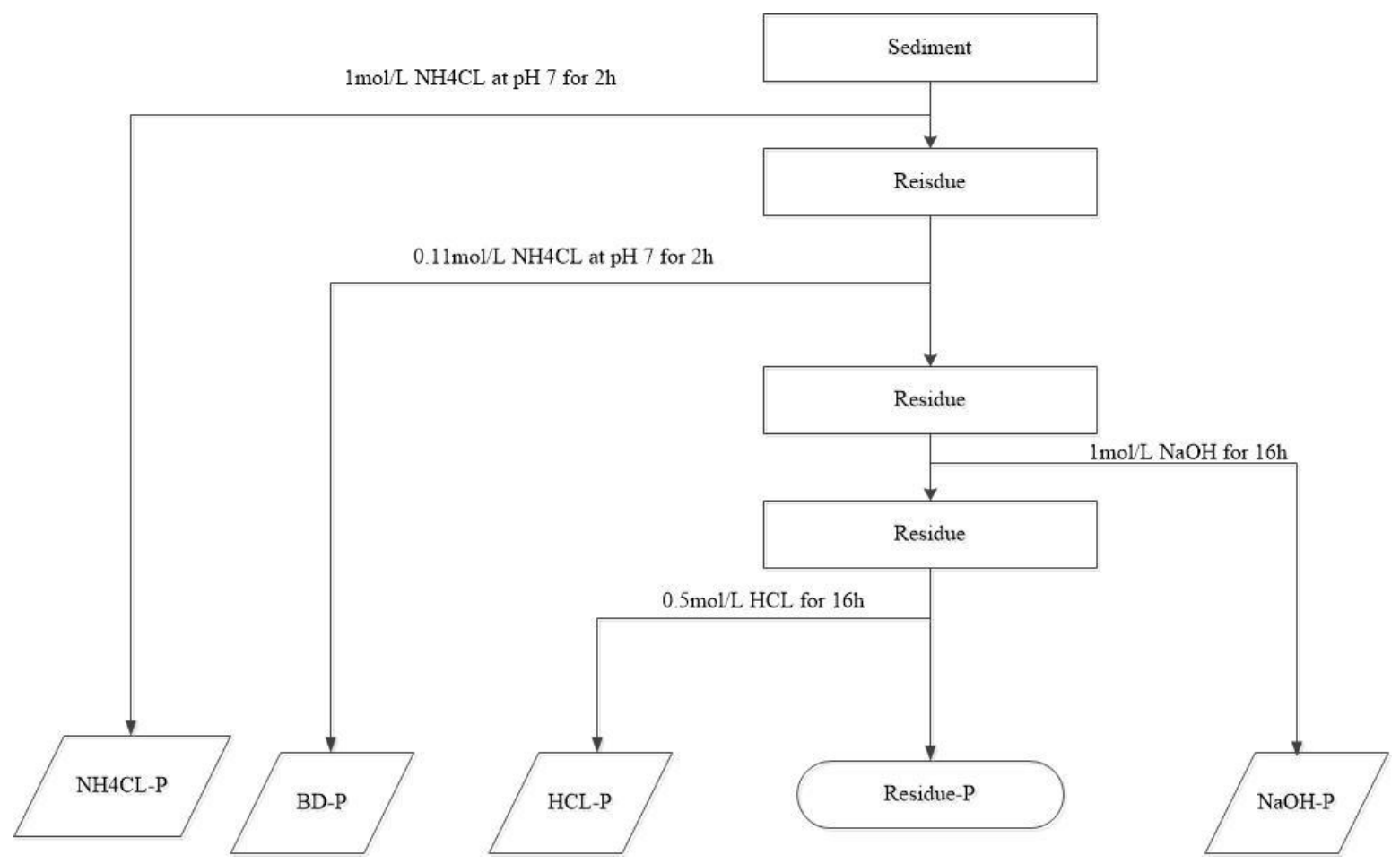

Fig 2. Sequential phosphorus fractions scheme

\subsection{Data statistics and analysis methods}

The data was computed using Microsoft Excel 2010. Origin 9.0 was used to draw the spatial changes of inorganic phosphorus fractions in sediment from the different watersheds. The correlation between sedimentary physico-chemical properties and $\mathrm{P}$ forms were exmined using Statistical Package for the Social Sciences (SPSS) 21.0.

\section{Results}

\subsection{Catchment Hongze and Sediment Characteristics}

Tables 1 and 2 outlines the reclassified land uses for Hongze watershed (Anhe and Suihe Rivers) and sediment properties. Among sites of Hongze watershed (Anhe and Suihe river), land-use intensive locations had a significantly higher impact compared to different sites.

This shows how suitable the land is for agricultural production. Sediment characteristics were seldom different between classes.

Table 1. Scheme of sampling site classification in the Anhe River

\begin{tabular}{ll}
\hline Sampling point & Description \\
\hline A1 & Shore bandwidth, sporadic housing \\
\hline A2 & Narrow shoreline with sporadic housing \\
\hline A3 & Shore bandwidth, sites \\
\hline A4 & Good water quality \\
\hline A5 & Small amount of water peanut \\
\hline
\end{tabular}




\begin{tabular}{ll}
\hline A6 & Fish pond, water peanut, Algae \\
\hline A7 & Ferry, reeds in water \\
\hline A8 & Small amount of water peanuts, raising crabs \\
\hline A9 & Small amount of water peanut \\
\hline A10 & Fishing boat, reed, water peanut \\
\hline
\end{tabular}

Table 2 Scheme of sampling sites classification in the Suihe River

\begin{tabular}{ll}
\hline Sampling sites & Description \\
\hline S1 & Shore bandwidth, wheat \\
\hline S2 & Rich in aquatic plants, River width 100 \\
\hline S3 & Sediment dark grey, River submerged plants, few trees along the River \\
\hline S4 & Grassland and woodlands on the other side \\
\hline S5 & lot of water peanuts \\
\hline S6 & Water surface 60-80m wide, water plants on the shore \\
\hline S7 & Large wheat fields around, good water quality \\
\hline S8 & Fishing boat, poultry farming \\
\hline
\end{tabular}

\subsection{Characteristics of sediment properties}

The general characteristics and chemical composition of sediment in different watersheds are shown in the table 3 and Table 4.

\subsubsection{Hongze watershed}

The $\mathrm{Ca}, \mathrm{Mn}, \mathrm{Fe}$, and OM content of the Suihe river were higher than that of the Anhe river. In Hongze watershed, the $\mathrm{pH}$ of the Suihe river was higher than Suihe river. At a high $\mathrm{pH}$, the phosphorus binding capacity of iron and aluminum compound decrease due to exchange reactions. In comparing the different watershed; for Hongze watershed, the TN contents of Anhe and Suihe rivers averaged $1114.44(789.29-1310.21) \mathrm{mg} / \mathrm{kg}$ and 1182.34 (923.72-1398.44) $\mathrm{mg} / \mathrm{kg}$ respectively, whereas for Tiaoxi watershed, TN contents of Dongtiaoxi and Xitaoixi rivers averaged 1244.24 (1102.68-1658.69) $\mathrm{mg} / \mathrm{kg}$ and 1438.00 (1133.64-1665.11) $\mathrm{mg} / \mathrm{kg}$, respectively.

The findings showed that concentration of $\mathrm{TN}$ in the Suihe River was greater than that of the Anhe River. In the case of TP contents, the Anhe and Suihe rivers (both belonging to the Hongze watershed) averaged 841.52 (514.71-1078-86) mg/kg and 675.12 (398.18-1093.10) mg/kg, respectively. In the Tiaoxi watershed, TP contents of Dongtiaoxi and Xitiaoxi rivers averaged 1056.43 (815.70$1302.60) \mathrm{mg} / \mathrm{kg}$ and 1373.76 (1186.03-1530.76) $\mathrm{mg} / \mathrm{kg}$, respectively. The comparison results showed that concentration of TP in the Anhe river was higher than that of Suihe river.

This suggests that the physicochemical properties of the various sediments display different concentrations due to the difference in watershed characteristics and pollution sources.

\subsubsection{Tiaoxi watershed}

The chemical characteristics of Dongtiaoxi and Xitiaoxi river sediments are presented in Table 2. Sediment properties such as $\mathrm{Al}_{2} \mathrm{O}_{3}, \mathrm{SiO}_{2}, \mathrm{OP}, \mathrm{IP}, \mathrm{TP}$, and $\mathrm{TN}$ varied greatly in the two rivers. The contents of $\mathrm{Al}_{2} \mathrm{O}_{3}, \mathrm{SiO}_{2}, \mathrm{OP}, \mathrm{IP}, \mathrm{TP}$, and $\mathrm{TN}$ in Dongtiaoxi River were 22.26-26.73\%, 55.16-75.88\%, $116.96-279.77 \mathrm{mg} / \mathrm{kg}, 698.74-1059.86 \mathrm{mg} / \mathrm{kg}, 815.70-1302.60 \mathrm{mg} / \mathrm{kg}$ and $1102.68-1658.69 \mathrm{mg} / \mathrm{kg}$, with an 
averages of $24.18 \%, 65.85 \%, 199.56 \mathrm{mg} / \mathrm{kg}, 856.87 \mathrm{mg} / \mathrm{kg}, 1056.43 \mathrm{mg} / \mathrm{kg}$ and $1244.24 \mathrm{mg} / \mathrm{kg}$, respectively.

For Xitiaoxi river, the content of $\mathrm{Al}_{2} \mathrm{O}_{3}, \mathrm{SiO}_{2}, \mathrm{OP}, \mathrm{IP}, \mathrm{TP}$, and $\mathrm{TN}$ in the sediments were 20.90$27.01 \%, 65.13-76.92 \%, 221.45-385.00 \mathrm{mg} / \mathrm{kg}, 888.96-1248.39 \mathrm{mg} / \mathrm{kg}, 1133.64-1665.11 \mathrm{mg} / \mathrm{kg}$ and $1186.03-$ $1530.76 \mathrm{mg} / \mathrm{kg}$, with averages of $24.09 \%, 71.10 \%, 308.16 \mathrm{mg} / \mathrm{kg}, 1065.60 \mathrm{mg} / \mathrm{kg}, 1373.76 \mathrm{mg} / \mathrm{kg}$ and $1438.00 \mathrm{mg} / \mathrm{kg}$, respectively. Thus, Xitiaoxi river is the most contaminated with relatively high IP, OP, TN, and TP contents.

In the Dongtiaoxi river, the content of $\mathrm{CaO}, \mathrm{MnO}_{2}$, and $\mathrm{Fe}_{2} \mathrm{O}_{3}$ in the sediments were 1.28-11.99\%, $0.07-0.23 \%$, and $5.95-7.60 \%$ with averages of $5.09 \%, 0.17 \%$ and $6.89 \%$, respectively. For Xitiaoxi river, the content of $\mathrm{CaO}, \mathrm{MnO}_{2}$, and $\mathrm{Fe}_{2} \mathrm{O}_{3}$ in the sediments were $0.66-6.05 \%, 0.06-0.23 \%$, and 4.92-7.76\% with averages of $1.58 \%, 0.11 \%$ and $6.52 \%$, respectively. These results indicate a higher concentration in the Dongtiaoxi river sediments compared to that of Xitiaoxi sediments, attributed to discharge from urban effluent which affects the chemical behaviour of phosphorus in the fluvial system.

There are some significant variations in chemical properties between the rivers Dongtiaoxi and Xitiaoxi. These differences were expected since the Dongtiaoxi River has greater pollutant inputs than the Xitiaoxi River Table 4. These findings suggest industrial effluent discharges of some of the major components of river sediment that influence the chemical activity of phosphorus in the river system., thus, the profound variation in the Xitiaoxi river.

Table 3 Phosphorus Sediment properties of Anhe River and Suihe River

\begin{tabular}{ccc}
\hline Contents & Anhe River & Suihe River \\
\hline $\mathrm{Al}(\%)$ & $10.11(7.52-12.07)$ & $10.20(7.92-14.05)$ \\
\hline $\mathrm{Ca}(\%)$ & $5.75(3.71-6.62)$ & $5.03(2.80-7.76)$ \\
\hline $\mathrm{Mn}(\%)$ & $0.06(0.01-0.17)$ & $0.05(0.00-0.09)$ \\
\hline $\mathrm{Fe}(\%)$ & $4.18(2.96-4.57)$ & $3.83(2.76-4.71)$ \\
\hline $\mathrm{OM}(\%)$ & $1.85(0.97-3.80)$ & $1.68(1.13-2.31)$ \\
\hline $\mathrm{TN}(\mathrm{mg} / \mathrm{kg})$ & $1114.44(789.29-1310.21)$ & $6752.34(923.72-1398.44)$ \\
\hline $\mathrm{TP}(\mathrm{mg} / \mathrm{kg})$ & $841.52(514.71-1078-86)$ & $7.96(7.66-8.32)$ \\
\hline $\mathrm{pH}(\mathrm{mg} / \mathrm{kg})$ & $8.18(7.97-8.66)$ & \\
\hline
\end{tabular}

Table 4 Phosphorus Sediment properties of Dongtiaoxi River and Xitiaoxi River

\begin{tabular}{ccc}
\hline Contents & Dongtiaoxi River & Xitiaoxi River \\
\hline $\mathrm{TOC} \%$ & $2.25(1.76-2.82)$ & $2.25(0.68-3.85)$ \\
\hline $\mathrm{Al}_{2} \mathrm{O}_{3} \%$ & $24.18(22.26-26.73)$ & $24.09(20.90-27.01)$ \\
\hline $\mathrm{SiO}_{2} \%$ & $65.85(55.16-75.88)$ & $71.10(65.13-76.92)$ \\
\hline $\mathrm{CaO} \%$ & $5.09(1.28-11.99)$ & $1.58(0.66-6.05)$ \\
\hline $\mathrm{MnO}_{2} \%$ & $0.17(0.07-0.23)$ & $0.11(0.06-0.23)$ \\
\hline $\mathrm{Fe} 2 \mathrm{O}_{3} \%$ & $6.89(5.95-7.60)$ & $6.52(4.92-7.76)$ \\
\hline $\mathrm{TP}(\mathrm{mg} / \mathrm{kg})$ & $1056.43(815.70-1302.60)$ & $1373.76(1186.03-1530.76)$ \\
\hline $\mathrm{OP}(\mathrm{mg} / \mathrm{kg})$ & $199.56(116.96-279.77)$ & $308.16221 .45-385.00)$ \\
\hline
\end{tabular}




\subsection{Comparison of spatial variation of different $P$ forms in river sediments}

The sediment phosphorus content was controlled by a many factors, such as sediment type and the rate of sedimentation. The phosphorus content showed a clear relation to the regional distribution [18]. The average relative distribution of different $P$ fractions in the sediment of different watersheds are presented in Fig. 2 and 3. The contents of TP and different $P$ fractions studied varied greatly.

The $\mathrm{P}$ fractions considered were inorganic $\mathrm{P}$ forms, including $\mathrm{NH}_{4} \mathrm{Cl}-\mathrm{P}, \mathrm{BD}-\mathrm{P}, \mathrm{NaOH}-\mathrm{P}$, and $\mathrm{HCl}-\mathrm{P}$ as well as organic $\mathrm{P}$ fractions. The spatial distribution of the fractions varied considerably in different reaches of the different watersheds, with a general increasing trend along the river inflow. The average contents of $\mathrm{NH}_{4} \mathrm{Cl}-\mathrm{P}, \mathrm{BD}-\mathrm{P}, \mathrm{NaOH}-\mathrm{P}$ and $\mathrm{HCl}-\mathrm{P}$ of Dongtiaoxi river are $4.93 \mathrm{mg} / \mathrm{kg}$, $128.55 \mathrm{mg} / \mathrm{kg}$, $309.52 \mathrm{mg} / \mathrm{kg}$, and $295.96 \mathrm{mg} / \mathrm{kg}$, respectively, while Xitiaoxi river recorded $3.40 \mathrm{mg} / \mathrm{kg}$, $271.72 \mathrm{mg} / \mathrm{kg}$, $384.10 \mathrm{mg} / \mathrm{kg}$, and $213.09 \mathrm{mg} / \mathrm{kg}$, respectively.

The various $P$ fractions in sediments are significantly influenced by land use changes and the geological layout of the watercourse [19]. The average content of phosphorus forms of Dongtiaoxi river was in the following sequence: $\mathrm{NaOH}-\mathrm{P}>\mathrm{HCl}-\mathrm{P}>\mathrm{BD}-\mathrm{P}>\mathrm{NH}_{4} \mathrm{Cl}-\mathrm{P}$; whereas that of Xitiaoxi river is in the order: $\mathrm{NaOH}-\mathrm{P}>\mathrm{BD}-\mathrm{P}>\mathrm{HCl}-\mathrm{P}>\mathrm{NH}_{4} \mathrm{Cl}-\mathrm{P}$. For the Hongze watershed, the average content of $\mathrm{NH}_{4} \mathrm{Cl}-\mathrm{P}, \mathrm{BD}-\mathrm{P}, \mathrm{NaOH}-\mathrm{P}$ and HCl-P in the Anhe River are $5.65 \mathrm{mg} / \mathrm{kg}, 81.53 \mathrm{mg} / \mathrm{kg}, 131.50 \mathrm{mg} / \mathrm{kg}$, and $278.47 \mathrm{mg} / \mathrm{kg}$, respectively. The sequence of $\mathrm{P}$ fractions was $\mathrm{NH}_{4} \mathrm{Cl}-\mathrm{P}>\mathrm{BD}-\mathrm{P}>\mathrm{NaOH}-\mathrm{P}>\mathrm{HCl}-\mathrm{P}$. The average of Suihe river are $7.82 \mathrm{mg} / \mathrm{kg}, 104.86 \mathrm{mg} / \mathrm{kg}$, $95.07 \mathrm{mg} / \mathrm{kg}$, and $251.32 \mathrm{mg} / \mathrm{kg}$ respectively.

The main rank order of Anhe river $\mathrm{P}$ fractions was $\mathrm{HCl}-\mathrm{P}>\mathrm{NaOH}-\mathrm{P}>\mathrm{BD}-\mathrm{P}>\mathrm{NH}_{4} \mathrm{Cl}-\mathrm{P}$, whereas Suihe river follows $\mathrm{HCl}-\mathrm{P}>\mathrm{BD}-\mathrm{P}>\mathrm{NaOH}-\mathrm{P}>\mathrm{NH}_{4} \mathrm{Cl}-\mathrm{P}$. These variations are due to various variables, such as particle size composition, redox potential, acidity, as well as environmental conditions associated with soil and sediment [20-23]. Sediment phosphorous content was high because of its high binding potential with sediment and minerals such as calcium, aluminum and iron [24].

$\mathrm{NH}_{4} \mathrm{Cl}-\mathrm{P}$ refers to loosely sorbed $\mathrm{P}$ in sediments. This fraction can contain dissolved $\mathrm{P}$ in pore water [25]. $\mathrm{NH}_{4} \mathrm{Cl}-\mathrm{P}$ is a seasonal variable phosphorous compound pool dissolved in interstitial water [20]. In Hongze watershed, the Anhe river concentrations of $\mathrm{NH}_{4} \mathrm{Cl}-\mathrm{P}$ in the sediments ranged from $2.55 \mathrm{mg} / \mathrm{kg} \sim 9.77 \mathrm{mg} / \mathrm{kg}$ with an average of $5.65 \mathrm{mg} / \mathrm{kg}$ whereas Suihe concentrations were 2.37 $\mathrm{mg} / \mathrm{kg} 14.78 \mathrm{mg} / \mathrm{kg}$ with an average $7.82 \mathrm{mg} / \mathrm{kg}$ for all sediment samples.

The highest concentration of $\mathrm{NH}_{4} \mathrm{Cl}-\mathrm{P}$ in the sediment of the Suihe River is the maximum concentration of sedimentary inorganic $\mathrm{P}$. This fraction of $\mathrm{P}$ makes up for $1.56 \%$ of the sedimentary inorganic $\mathrm{P}$ in the Hongze watershed. BD-P is a the redox-sensitive $\mathrm{P}$ fraction, consisting mainly of Mn compounds and $\mathrm{P}$ bound to Fe hydroxides [26].

The BD-P reagent reduces the oxidized species of iron and manganese and thereby releasing the phosphorous adsorbed oxide of the two metals. Iron - bound P determined by BD extraction has been Shown to provide the best estimate of internal P loading. BD-P represents the redox - sensitive P forms that are considered a potential mobile pool of $P$ and are algal available [20].

$\mathrm{NaOH}-\mathrm{P}$ is exchangeable including $\mathrm{P}$ bound to metal oxides, mainly of $\mathrm{Al}$ and $\mathrm{Fe}$ [25]. $\mathrm{NaOH}$ extractable phosphorus may be discharged at the sediment-water interface for growth of phytoplankton under anaerobic environment [27]. Active $\mathrm{Fe}$ and $\mathrm{Al}$ were considered to be the key adsorbents of $\mathrm{P}$ in sediments [28]. BD-P and $\mathrm{NaOH}-\mathrm{P}$ are principally bound to $\mathrm{Fe}$ and $\mathrm{Al}$, notably in their amorphous and active forms. 
$\mathrm{HCl}-\mathrm{P}$ is a low $\mathrm{pH}$ sensitive $\mathrm{P}$ fraction and is presumed to consist entirely of apatite $\mathrm{P}$, including $\mathrm{P}$ bound to carbonates and traces of organic hydrolysable $\mathrm{P}$ [25]. Calcium bound $\mathrm{P}$ is a reasonably stable sedimentary fraction of $P$ and leads to a lasting burial $P$ in sediments [25]. This $P$ fraction was considered to be a relatively stable IP fraction in sediment $[25,29]$.

\subsection{Bioavailable phosphorus (BAP) in the sediments}

Bioavailable phosphorus can be converted to be usable by physical, chemical and biological cycles. This also depends on the chemical environment: environmental factors such as $\mathrm{pH}$, redox potential are influences mobilization; etc. Bioavailable phosphorus is calculated as the sum of available $\mathrm{P}$ and $\mathrm{P}$, which can be transformed by natural phenomena into free form.

The BAP was estimated as the summation of $\mathrm{NH}_{4} \mathrm{Cl}-\mathrm{P}, \mathrm{BD}-\mathrm{P}$ and $\mathrm{NaOH}-\mathrm{P}$ and is described to as inorganic $\mathrm{P}$ non-apatite [30]. Of these, the available $\mathrm{P}$ fraction of $\mathrm{NaOH}-\mathrm{P}$ has the highest algal. Past studies reported that the bioavailable fraction of phosphorus typically consists of the $\mathrm{P}$ fractions adsorbed and combined with metal. Nevertheless, micro-organisms may have access to a portion of the organic phosphorus or calcium-related fraction [31].

In the current study, the scheme proposed is $\mathrm{BAP}=\mathrm{NH} 4 \mathrm{Cl}-\mathrm{P}+\mathrm{NaOH}-\mathrm{P}+\mathrm{BD}-\mathrm{P}$. The potential bioavailable phosphorus can contribute significantly to local primary production when this fraction enters the water column. This may be due to resuspension or bioturbation.
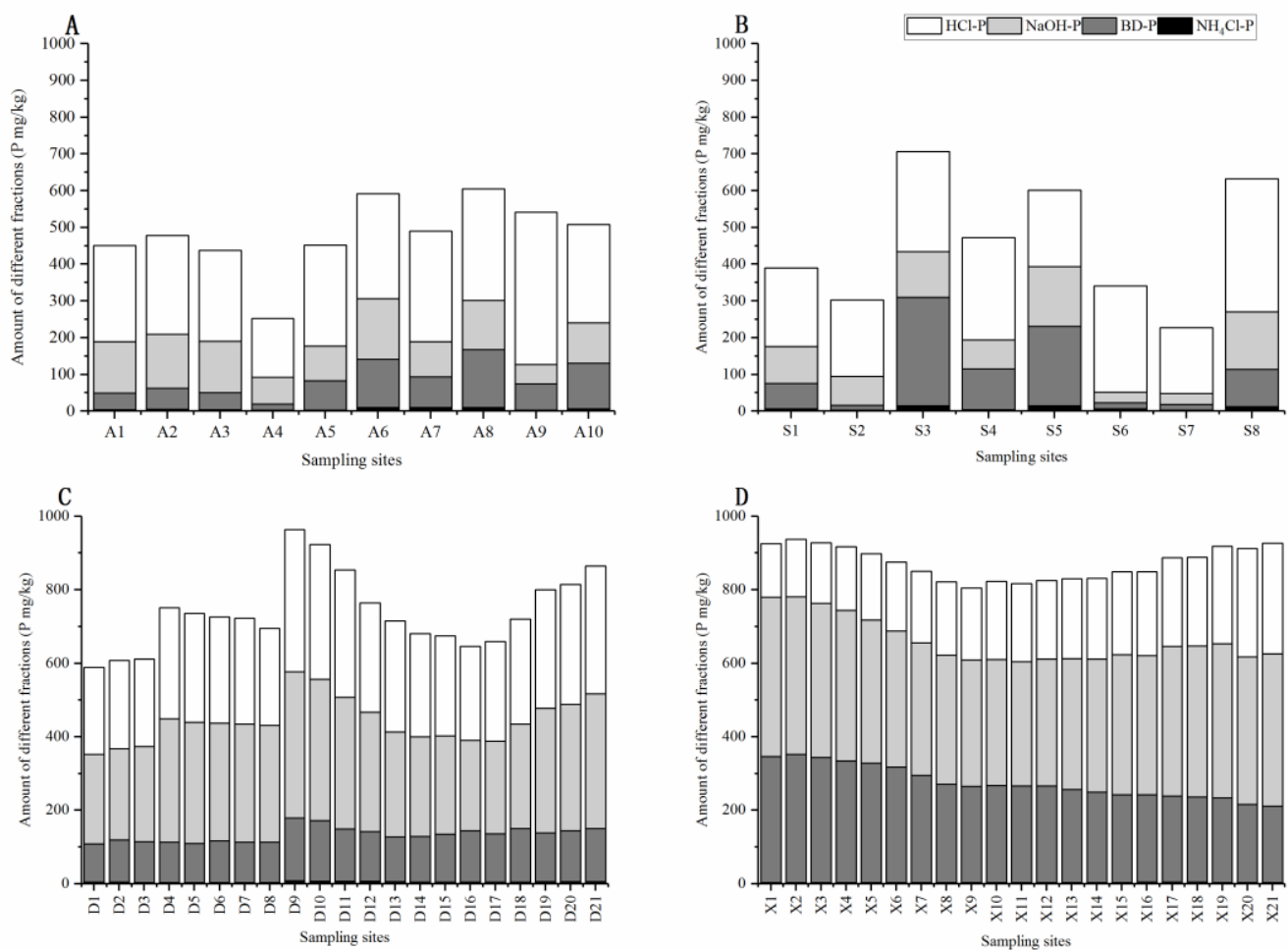

Fig. 2 The concentration of different $\mathrm{P}$ fractions in different sediments of Hongze and Tiaoxi watersheds 

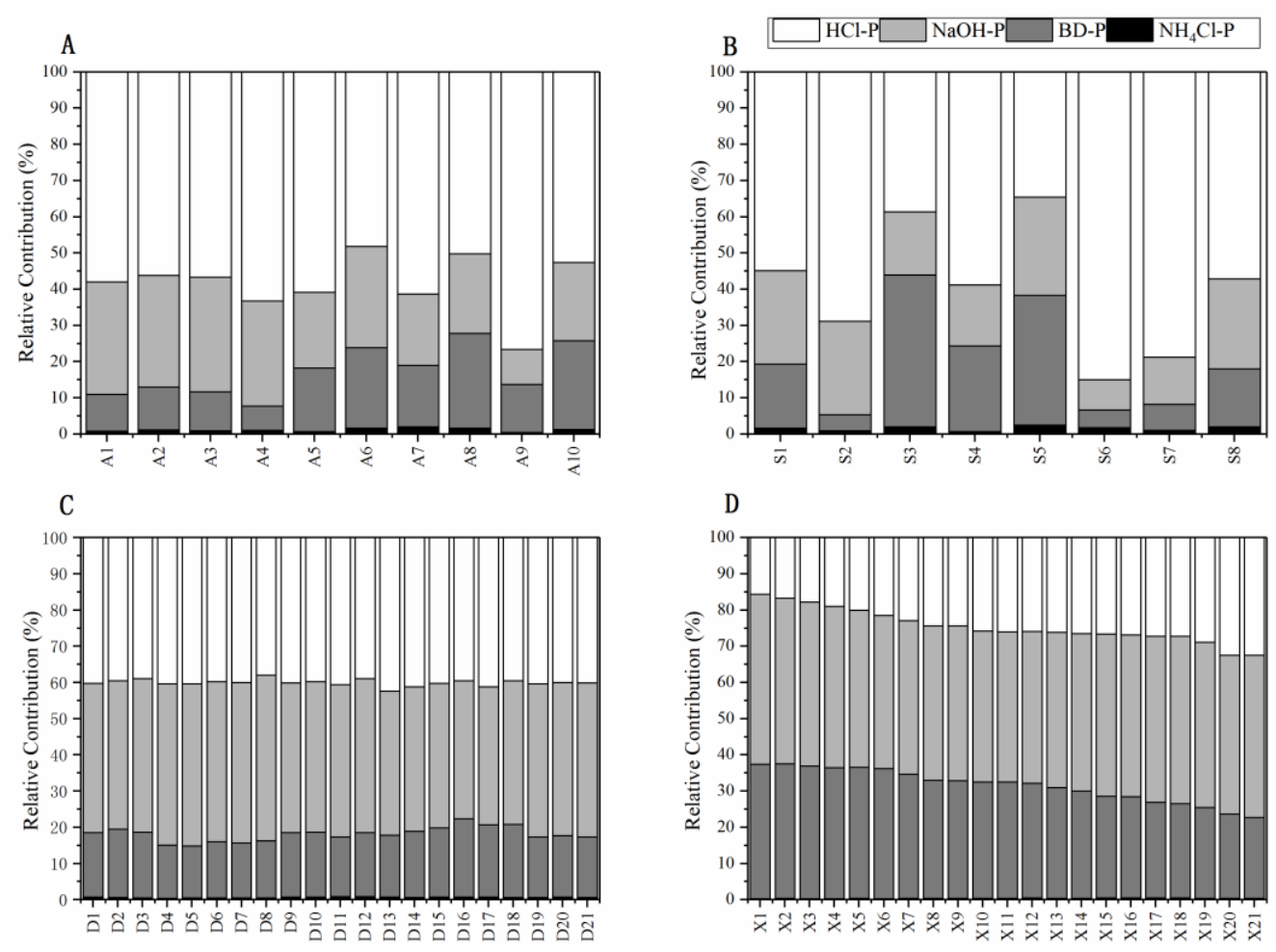

Fig.3 The relative contribution of different $P$ fractions to IP in different sediments of Hongze and

Tiaoxi watersheds

\subsection{Relationship between P fraction and sediment composition of different watersheds}

The connection between the different $\mathrm{P}$ forms in the sediments and their physicochemical properties was evaluated to understand the sediment's effect and composition on the distribution of $\mathrm{P}$ forms in the sediment. (Table 6). The correlation result reveals that IP and TP have a stronger correlation with $\mathrm{NaOH}-\mathrm{P}$ and $\mathrm{HCl}-\mathrm{P}$ in sediments, while the TOC and $\mathrm{MnO}_{2}$ in Dongtiaoxi River had a significant negative connection to $\mathrm{NH}_{4} \mathrm{Cl}-\mathrm{P}$ and BD-P.

TN had a significant positive correlative with $\mathrm{NH}_{4} \mathrm{Cl}-\mathrm{P}, \mathrm{BD}-\mathrm{P}, \mathrm{NaOH}-\mathrm{P}$, and $\mathrm{HCl}-\mathrm{P}$. Also, the correlation between the different fractions of $\mathrm{P}$ in the sediment and the physico-chemical characteristics of the sediments are presented in Table 6. There was no significant relationship between $\mathrm{Al}_{2} \mathrm{O}_{3}, \mathrm{SiO}_{2}, \mathrm{CaO}, \mathrm{Fe}_{2} \mathrm{O}_{3}$, and $\mathrm{OP}$. Meanwhile, in the Xitiaoxi River, BD-P negatively correlated with $\mathrm{CaO}$ and TN. HCl-P contents were significantly positively correlated with $\mathrm{CaO}$. A higher TOC concentration in the sediment coupled with a smaller particle size contributes to a stronger capacity of $\mathrm{P}$ adsorption [9].

Table 5 demonstrates the relationships between phosphorus fractions and sediment characteristics in Hongze watershed. $\mathrm{Al}$ in the Anhe River positively correlated with $\mathrm{NH}_{4} \mathrm{Cl}-\mathrm{P}$, BD-P and $\mathrm{HCl}-\mathrm{P}$. Ca positively correlated with BD-P, and Fe significantly positively correlated with $\mathrm{NaOH}-$ P. HCl-P significantly positively correlated with $\mathrm{Al}, \mathrm{Ca}$ and $\mathrm{pH}$. In the Suihe River, $\mathrm{Al}, \mathrm{Fe}, \mathrm{OM}$, and TP were highly and positively connected with $\mathrm{NH}_{4} \mathrm{Cl}-\mathrm{P}$, BD-P and NaOH-P.

$\mathrm{Ca}$ and $\mathrm{pH}$ were significantly positively correlated with HCl-P. This demonstrates that BD-P and $\mathrm{NH}_{4} \mathrm{Cl}-\mathrm{P}$ may be released easily from the sediment in Suihe River, and they were the principal fractions of the released phosphorus sources in the river sediments.

Table 5 Pearson correlation of sediment properties and phosphorus forms of Hongze watershed 


\begin{tabular}{lllllllll}
\hline \multicolumn{9}{c}{ Anhe River } \\
\hline Contents & $\mathrm{NH}_{4} \mathrm{Cl}-\mathrm{P}$ & $\mathrm{BD}-\mathrm{P}$ & $\mathrm{NaOH}-\mathrm{P}$ & $\mathrm{HCl}-\mathrm{P}$ & $\mathrm{NH}+\mathrm{Cl}-\mathrm{P}$ & $\mathrm{BD}-\mathrm{P}$ & $\mathrm{NaOH}-\mathrm{P}$ & $\mathrm{HCl}-\mathrm{P}$ \\
\hline $\mathbf{A l}$ & $0.633^{*}$ & $0.854^{* *}$ & 0.151 & $0.649^{*}$ & $0.813^{*}$ & $0.976^{* *}$ & $0.708^{*}$ & 0.332 \\
\hline $\mathbf{C a}$ & 0.484 & $0.662^{*}$ & 0.041 & $0.787^{* *}$ & 0.267 & 0.226 & 0.086 & $0.924^{* *}$ \\
\hline $\mathbf{M n}$ & 0.137 & 0.202 & -0.213 & -0.303 & -0.403 & -0.496 & -0.318 & 0.679 \\
\hline $\mathbf{F e}$ & 0.582 & 0.421 & $0.939^{* *}$ & -0.153 & $0.794^{*}$ & $0.770^{*}$ & $0.976^{* *}$ & 0.261 \\
\hline $\mathbf{O M}$ & 0.200 & 0.085 & 0.412 & 0.191 & $0.931^{* *}$ & $0.907^{* *}$ & $0.817^{*}$ & 0.285 \\
\hline TN & 0.395 & 0.469 & 0.555 & 0.496 & 0.408 & 0.141 & 0.351 & 0.506 \\
\hline TP & 0.506 & 0.470 & 0.523 & 0.401 & $0.932^{* *}$ & $0.867^{* *}$ & $0.907^{* *}$ & 0.321 \\
\hline $\mathbf{p H}$ & 0.211 & 0.469 & -0.366 & $0.878^{* *}$ & 0.133 & -0.063 & 0.004 & $0.935^{* *}$ \\
\hline
\end{tabular}

Table 6 Pearson correlation of sediment properties and phosphorus forms of Tiaoxi watershed

\begin{tabular}{lllllllll}
\hline \multicolumn{3}{c}{ Dongtiaoxi River } & \multicolumn{5}{c}{ Xitiaoxi River } \\
\hline Contents & $\mathrm{NH}_{4} \mathrm{Cl}-\mathrm{P}$ & $\mathrm{BD}-\mathrm{P}$ & $\mathrm{NaOH}-\mathrm{P}$ & $\mathrm{HCl}-\mathrm{P}$ & $\mathrm{NH}_{4} \mathrm{Cl}-\mathrm{P}$ & $\mathrm{BD}-\mathrm{P}$ & $\mathrm{NaOH}-\mathrm{P}$ & $\mathrm{HCl}-\mathrm{P}$ \\
\hline $\mathbf{T O C}$ & $-0.808^{* *}$ & $-0.770^{* *}$ & -0.087 & -0.405 & 0.168 & -0.198 & -0.031 & 0.279 \\
\hline $\mathrm{Al}_{2} \mathrm{O}_{3}$ & -0.342 & -0.327 & 0.003 & -0.095 & -0.015 & 0.267 & 0.072 & -0.140 \\
\hline $\mathrm{SiO}_{2}$ & -0.033 & -0.116 & 0.281 & 0.237 & -0.038 & 0.098 & -0.029 & -0.290 \\
\hline $\mathbf{C a O}$ & 0.077 & 0.225 & -0.202 & -0.184 & -0.037 & $-0.449^{*}$ & 0.251 & $0.680^{* *}$ \\
\hline $\mathrm{MnO}_{2}$ & $-0.539^{*}$ & $-0.461^{*}$ & -0.240 & -0.373 & 0.062 & 0.004 & -0.085 & 0.080 \\
\hline $\mathrm{Fe}_{2} \mathbf{O}_{3}$ & -0.330 & -0.257 & -0.017 & -0.075 & 0.409 & -0.153 & -0.157 & 0.152 \\
\hline $\mathbf{I P}$ & $0.505^{*}$ & 0.346 & $0.785^{* *}$ & $0.667^{* *}$ & 0.372 & -0.232 & 0.181 & 0.154 \\
\hline $\mathbf{O P}$ & -0.369 & -0.397 & 0.327 & 0.019 & -0.235 & 0.059 & -0.047 & 0.004 \\
\hline $\mathbf{T P}$ & 0.245 & 0.113 & $0.726^{* *}$ & $0.524^{*}$ & 0.327 & -0.257 & 0.200 & 0.197 \\
\hline $\mathbf{T N}$ & $0.719^{* *}$ & $0.754^{* *}$ & $0.843^{* *}$ & $0.862^{* *}$ & 0.399 & $-0.502^{*}$ & -0.073 & 0.421 \\
\hline $\mathrm{P}<0.05^{*}$ & $\mathbf{P}$ & $0.01 *$ & & & &
\end{tabular}

$\mathrm{P}<0.05^{*}, \mathrm{p}<0.01^{* *}$ Correlation is significant at $0.05^{* *}$ Correlation is significant at 0.01

\section{Discussion}

\subsection{Environmental significance}

These results have impacted the environment of the different watersheds that flow into the lake. If environmental managers determine that $\mathrm{P}$ is a problem in the receiving watershed, they can manage the release of P. [32] found that the significance of the source is supported by the spatial pattern and speciation of $\mathrm{P}$ (total $\mathrm{P}$ and inorganic $\mathrm{P}$ ) in the upstream and downstream testing sites of the major fishing region. As environmental conditions change, phosphorus can be expelled from the soil into the surrounding water. The most essential variables can be estimated from domestic activities in urban and rural areas, agricultural production, and fertilizer use, contributing $\mathrm{P}$ to the river through soil loss and atmospheric deposition. This depends on the region, soil type and retention ability, as well as on the environment [32].

Therefore, it is crucial to comprehend the concentration of mobile phosphorus forms that could provide useful insights into understanding Lake Eutrophication. These findings indicate that the distribution of phosphorus in sediments may be enormous and may be a dominant factor in the quality of water when external phosphorus loading is reduced. 
The upsurge in overflows of nutrients from land to environment are the waste material-products of human activity sectors like agriculture and industrialization. Due to this, changes in land use are important factors that could alter the nutrient concentration in watersheds [33]. Phosphorus concentration shows different responses to anthropogenic sources from different pathways and sources [34,35].

Approximately $80 \%$ of the direct discharge of domestic waste into the lake is due to external loading from the catchment area, which is dominated by farmlands and the intensive internal loading from the bottom sediment [36]. Besides, the effect of watershed area and river depth, as well as the time differential in transport of contaminants in the watercourse, are the key reasons for variations in sedimentary flux [37].

The existence of humans in the river basin normally leads to an increase in nutrient transport, worsening the cycle of deterioration of the lake [38]. As a consequence of agriculture and industry growth in Eastern China, freshwater concentrations of $\mathrm{P}$ have intensified due to excessive use of fertilizer and too much wastewater discharge [3].

\subsection{Implication for watershed management}

These results have implication for the management of the different watersheds flowing into the lake. Landscape patterns have been characterized by certain geographical factors, such as topography , climate, geology and land use or types of land cover [39,40]. Rivers are especially susceptible because of their nearness to cities and towns and sensitivite to land-use changes [41,42].

Watersheds appeal to many environmental managers as they have well-defined boundaries that allow for the determination of relative water and solute budgets. Many of the watersheds are altered by humans, atmospheric deposition, forestry and floodplain management, eutrophication and other types of biogeochemical hydrological changes in freshwater [43]. These transformations can either reduce or increase their performance under increasing environmental conditions.

Differences in water and sediment in watershed lakes may lead to the development of substantially different lake ecosystems. The watershed variables were found to be the consolidated factors in the upstream landscape of the sampling stations and the geomorphological conditions of the sampling sites, as well as the mean slope and distance from the river channel $[44,45]$. The challenge is to be able to focus on much research for a broader understanding of the watershed which is useful to environmental managers [45].

Zhang et al [46] proved the behaviour of anthropogenic $\mathrm{P}$ in a watershed given a significant human activity, and landscape topography. Inputs of $\mathrm{P}$ and exports across the river basin are influenced along such gradient. Nutrient concentration in rivers is of vital importance to the ecosystems of the river itself. The transfer of nutrients by river is indeed also important for any other receiving media [33].

Rising human induced operation coupled with current land use will enhance pollutant loads, such as nutrients and microbes, into water sources which can threaten human health [47], whereas rainfall events [48]. This may further increase the loading of contaminants due to the emergence of runoff from both agricultural and residential areas as a result of livelihood activities, including the use of compost as fertilizer and animal grazing at river banks [49]. If environmental managers determine that $\mathrm{P}$ is a problem in the receiving watershed, they can manage to maintain greater aerobic conditions, thereby reducing the release of $\mathrm{P}$. 
Additionally, a significant release of $\mathrm{P}$ from different watersheds under aerobic conditions has implications for water quality. Freshwater discharges have been impacted by water withdrawals for urbanization, irrigation and aquaculture, reducing the dilution potential of the estuary and increasing the harmful impact of nitrogen emissions from anthropogenic sources [50].

\section{Conclusions}

This study showed the characteristics of $P$ fractions in river sediments and its influence factors in Hongze and Tiaoxi watersheds. The spatial distribution characteristics of the TP and phosphorus fractions in the sediments differed significantly in the Tiaoxi watershed. TP contents ranged from $815.70 \mathrm{mg} / \mathrm{kg} \sim 1302.60 \mathrm{mg} / \mathrm{kg}$ (DTX) and from $1186.03 \mathrm{mg} / \mathrm{kg} \sim 1530.76 \mathrm{mg} / \mathrm{kg}$ (XTX) with the mean value of $1056.43 \mathrm{mg} / \mathrm{kg}$ and $1373.76 \mathrm{mg} / \mathrm{kg}$ in Tiaoxi watershed. The average of Tiaoxi's P fractions was greater than in the Hongze watershed.

$\mathrm{NH}_{4} \mathrm{Cl}-\mathrm{P}$ and BD-P can be easily released from sediments and can contribute mainly to the release of phosphorus in the sediment of the Hongze watershed. The phosphorus fraction of $\mathrm{CaO}$, $\mathrm{MnO}_{2}$, and $\mathrm{Fe}_{2} \mathrm{O}_{3}$ in Dongtiaoxi River was higher than in Xitiaoxi River, whereas $\mathrm{SiO}_{2}, \mathrm{TP}, \mathrm{OP}, \mathrm{IP}, \mathrm{TN}$ in Xitiaoxi River were mainly P pollution. Influence factor $P$ in sediments was controlled by chemical action. The potential of $\mathrm{P}$ adsorption was higher and the sediment had a high adsorption rate for $\mathrm{NaOH}-\mathrm{P}$ and HCl-P in different watersheds.

As a source, the sediments would desorb P into the river sediment and into the overflowing water. The dominant fractions of extractable phosphorus forms that increase loading to the river, as well as improving ecological diversity. Thus, it is need to further improve to manage watersheds such as the Xitiaoxi River, if the watershed as a whole is to be successfully controlled.

Author Contributions: “Conceptualization, J.B.M., and X.Y.; methodology, J.B.M., X.Y., H.Z.,; formal analysis, J.B.M., and X.Y.; resources, X.Y.; writing-original draft preparation, J.B.M..; writingreview and editing, I.KN., S.O.Y.A., N.A.P., E.N., T.K.Y., Z.M.K supervision, X.Y.; funding acquisition, X.Y.

Funding: This work is supported by the Chinese National Science Foundation (No. 41372354), The International Technology Cooperation and Exchange Fund from the Chinese Ministry of Science and Technology (2012DFA60830). This work was also supported by the Priority Academic Program Development of Jiangsu Higher Education Institutions (PPZY2015A51).

Acknowledgments: We are grateful to the funding agencies for supporting this work. We also appreciate all the team members who supported this work.

Conflicts of Interest: The authors declare no conflict of interest.

\section{References}

1. Yang, W.Q.; Xiao, H.; Li, Y.; Miao, D.R. Vertical distribution and release characteristics of phosphorus forms in the sediments from the river inflow area of dianchi lake, china. Chemical Speciation $\mathcal{E}$ Bioavailability 2018, 30, 14-22.

2. Daneshgar, S.; Callegari, A.; Capodaglio, A.G.; Vaccari, D. The potential phosphorus crisis: Resource conservation and possible escape technologies: A review. Resources 2018, 7, 37.

3. Zhang, W.; Jin, X.; Zhu, X.; Shan, B.; Zhao, Y. Phosphorus characteristics, distribution, and relationship with environmental factors in surface sediments of river systems in eastern china. Environmental Science and Pollution Research 2016, 23, 19440-19449. 
4. Pernet-Coudrier, B.; Qi, W.; Liu, H.; Muller, B.; Berg, M. Sources and pathways of nutrients in the semiarid region of beijing-tianjin, china. Environmental Science \& Technology 2012 46, 5294-5301.

5. Wang, C.; Zhang, Y.; Li, H.; Morrison, R.J. Sequential extraction procedures for the determination of phosphorus forms in sediment. Limnology 2013, 14 147-157.

6. Wang, S.; Jin, X.; Pang, Y.; Zhao, H.; Zhou, X.; Wu, F. Phosphorus fractions and phosphate sorption characteristics in relation to the sediment compositions of shallow lakes in the middle and lower reaches of yangtze river region, china. Journal of Colloid and Interface Science 2005, 289, 339-346.

7. Wang, F.; Liu, C.; Wu, M.; Yu, Y.; Wu, F.; Lü, S.; Xu, G. Stable isotopes in sedimentary organic matter from lake dianchi and their indication of eutrophication history. Water, Air, and Soil Pollution 2009, 199, 159-170.

8. Dong, L.; Yang, Z.; Liu, X. Phosphorus fractions, sorption characteristics, and its release in the sediments of baiyangdian lake, china. Environmental Monitoring and Assessment 2011, 179, 335-345.

9. Liu, J.; Luo, X.; Zhang, N.; Wu, Y. Phosphorus released from sediment of dianchi lake and its effect on growth of microcystis aeruginosa. Environmental Science and Pollution Research 2016, 23, 16321-16328.

10. Sarpong, L.; Li, Y.; Norgbey, E.; Nwankwegu, A.S.; Cheng, Y.; Nasiru, S.; Nooni, I.K.; Setordjie, V.E. A sediment diagenesis model of seasonal nitrate and ammonium flux spatial variation contributing to eutrophication at taihu, china. International Journal of Environmental Research and Public Health 2020, 17, 4158.

11. Jingfu, W.; Jingan, C.; Dallimore, C.; Haiquan, Y.; Zhihui, D. Spatial distribution, fractions, and potential release of sediment phosphorus in the hongfeng reservoir, southwest china. Lake and Reservoir Management 2015, 31, 214-224.

12. Luo, H.J.; Liu, D.F.; Huang, Y.P. Nitrogen characteristics in sediments of xiangxi bay, china three-gorge reservoir. Water and Environment Journal 2014, 28, 45-51.

13. Song, Q.W.; Li, Y.F.; Jiang, X. Spatial distribution of phosphorus fractions in the sediments of meiliang bay, taihu lake, china. Advanced Materials Research 2013, 610 2766-2770.

14. Shujuan, S.U.N.; Huang, S.; Xueming, S.U.N.; Wei, W.E.N. Phosphorus fractions and its release in the sediments of haihe river, china. Journal of Environmental Sciences 2009, 21, 291-295.

15. Marip, J.B.; Yuab, X.; Zhu, H.; Xu, J.; Ye, H.; Zhou, H.; Nooni, I.K.; Amankwah, S.O.Y.; Prempeh, N.A.; Norgbey, E. Spatial variations in and environmental significance of nitrogen forms in river sediments from two different watersheds in eastern china. Environmental Monitoring and Assessment 2020, 192, 112.

16. Psenner, R. Fractionation of phosphorus in suspended matter and sediment. Arch Hydrobiol Beih 1988, 30, 98-110.

17. Hupfer, M.; Gtichter, R.; Ruegger, R.R. Polyphosphate in lake sediments: 31p nmr spectroscopy as a tool for its identification. Limnology and Oceanography 1995, 40 610-617.

18. Xiang, S.L.; Zhou, W.B. Phosphorus forms and distribution in the sediments of poyang lake, china. International Journal of Sediment Research 2011, 26, 230-238.

19. Poulenard, J.; Dorioz, J.M.; Elsass, F. Analytical electron microscopy fractionation of fine and colloidal particulate-phosphorus in riverbed and suspended sediments. Aquatic Geochemistry 2008, 14, 193-210.

20. Zhou, A.; Tang, H.; Wang, D. Phosphorus adsorption on natural sediments: Modeling and effects of ph and sediment composition. Water Research 2005, 39, 1245-1254.

21. Young, E.O.; Ross, D.S. Total and labile phosphorus concentration as influenced by riparian buffer soil properties. Journal of environmental quality 2016, 31, 294-304. 
22. Maguire, R.O.; Sims, J.T. Soil testing to predict phosphorus leaching. Journal of environmental quality 2002, 31, 1601-1609.

23. Su, J.; van Bochove, E.; Auclair, J.C.; Theruault, G.; Denault, J.T.; Bosse, C.; Hu, C. Phosphorus algal availability and release potential in suspended and streambed sediments in relation to sediment and catchment characteristics. Agriculture, ecosytems and environment 2014, 188.

24. Clarke, S.J.; Wharton, G. Sediment nutrient characteristics and aquatic macrophytes in lowland english rivers. Science of the Total Environment 2001, 266, 103-112.

25. Kaiserli, A.; Voutsa, D.; Samara, C. Phosphorus fractionation in lake sediments-lakes volvi and koronia, n. Greece. Chemosphere 2002, 46 1147-1155.

26. Kozerski, H.P.; Kleeberg, A. The sediments and benthic-pelagic exchange in the shallow lake müggelsee (berlin, germany). International Review of Hydrobiology 1998, 83, 77-112.

27. Ting, D.S.; Appan, A. General characteristics and fractions of phosphorus in aquatic sediments of two tropical reservoirs. Water Science and Technology 1996, 34, 53-59.

28. Danen-Louwerse, H.; Lijklema, L.; Coenraats, M. Iron content of sediment and phosphate adsorption properties. Hydrobiologia 1993, 253, 311-317.

29. Gonsiorczyk, T.; Casper, P.; Koschel, R. Phosphorus-binding forms in the sediment of an oligotrophic and an eutrophic hardwater lake of the baltic lake district (germany). Water Science and Technology 1998, $37,51-58$.

30. Stone, M.; English, M.C. In Geochemical composition, phosphorus speciation and mass transport of fine-grained sediment in two lake erie tributaries, Third International Workshop on Phosphorus in Sediments Dordrecht, 1993; Springer: Dordrecht, pp 17-29.

31. de Jonge, V.N.; Engelkes, M.M.; Bakker, J.F. Bio-availability of phosphorus in sediments of the western dutch wadden sea. Hydrobiologia 1993, 253, 151-163.

32. Marins, R.V.; Paula Filho, F.J.; Eschrique, S.A.; Lacerda, L.D. Anthropogenic sources and distribution of phosphorus in sediments from the jaguaribe river estuary, ne, brazil. Brazilian Journal of Biology 2011, 71, 673-678.

33. Salvia-Castellví, M.; Iffly, J.F.; Vander Borght, P.; Hoffmann, L. Dissolved and particulate nutrient export from rural catchments: A case study from luxembourg. Science of the Total Environment 2005, 344, 51-65.

34. Gravelle, J.A.; Ice, G.; Link, T.E.; Cook, D.L. Nutrient concentration dynamics in an inland pacific northwest watershed before and after timber harvest. Forest Ecology and Management 2009, 257, 1663 1675 .

35. Annan, K.; Dickson, R.A.; Amponsah, I.K.; Nooni, I.K. The heavy metal contents of some selected medicinal plants sampled from different geographical locations. Pharmacognosy Research 2013, 5, 103108.

36. Kowalczewska-Madura, K.; Gołdyn, R. Anthropogenic changes in water quality in the swarzędzkie lake (west poland). Limnological Review 2006, 6, 147-154.

37. Ouyang, W.; Yang, W.; Tysklind, M.; Xu, Y.; Lin, C.; Gao, X.; Hao, Z. Using river sediments to analyze the driving force difference for non-point source pollution dynamics between two scales of watersheds. Water Research 2018, 139, 311-320.

38. Szyper, H.; Gołdyn, R. Role of catchment area in the transport of nutrients to lakes in the wielkopolska national park in poland. Lakes $\mathcal{E}$ Reservoirs: Research $\mathcal{E}$ Management 2002, 7, 25-33. 
39. Frissell, C.A.; Liss, W.J.; Warren, C.E.; Hurley, M.D. A hierarchical framework for stream habitat classification: Viewing streams in a watershed context. Environmental Management 1986, 10, 199-214.

40. Schoonover, J.E.; Lockaby, B.G.; Pan, S. Changes in chemical and physical properties of stream water across an urban-rural gradient in western georgia. Urban Ecosystems 2005, 8, 107-124.

41. Withers, P.J.A.; Jarvie, H.P. Delivery and cycling of phosphorus in rivers: A review. Science of the Total Environment 2008, 400, 379-395.

42. Nooni, I.K.; Duker, A.A.; van Duren, I.; Addae-Wireko, L.; Osei Jnr, E.M. Support vector machine to map oil palm in a heteorogenous environment. International Journal of Remote Sensing 2014, 35, 47784794.

43. Humborg, C.; Andersen, H.E.; Blenckner, T.; Gadegast, M.; Giesler, R.; Hartmann, J.; Venohr, M. Environmental impacts-freshwater biogeochemistry. Springer: Cham, 2015.

44. Cui, L.; Li, W.; Gao, C.; Zhang, M.; Zhao, X.; Yang, Z.; Ma, W. Identifying the influence factors at multiple scales on river water chemistry in the tiaoxi basin, china. Ecological Indicators 2018, 92, 228-238.

45. Baddoo, T.D.; Li, Z.; Guan, Y.; Boni, K.R.C.; Nooni, I.K. Data-driven modelling and the influence of objective function selection on model performance in limited data regions. International Journal of Environmental Research and Public Health 2020, 17, 4132.

46. Zhang, W.; Swaney, D.P.; Hong, B.; Howarth, R.W. Anthropogenic phosphorus inputs to a river basin and their impacts on phosphorus fluxes along its upstream-downstream continuum. Journal of Geophysical Research: Biogeosciences 2017, 122, 3273-3287.

47. Carroll, S.P.; Dawes, L.A.; Goonetilleke, A.; Hargreaves, M. Water quality profile of an urbanising catchment-ningi creek catchment.Technical report. School of Urban Development, Q.U.o.T.C.S.C., Ed. QLD: Australia, 2006; pp 1-93.

48. Bhatti, A.S.; Wang, G.; Ullah, W.; Ullah, S.; Hagan, D.F.T.; Nooni, I.K.; Lou, D.; Ullah, I. Trend in extreme precipitation indices based on long term in situ precipitation records over pakistan. Water 2020, 12, 797.

49. Ackerman, D.; Weisberg, S.B. Relationship between rainfall and beach bacterial concentrations on santa monica bay beaches. Journal of Water and Health 2003, 1, 85-89.

50. Dias, F.J.S.; Marins, R.V.; Maia, L.P. Hydrology of a well-mixed estuary at the semi-arid northeastern brazilian coast. Acta Limnologica Brasiliensia 2009, 21, 377-385. 